\title{
Geochemistry and metamorphism of the Mouriscas Complex, Ossa-Morena/Central Iberian zone boundary, Iberian Massif, Central Portugal: Implications for the Cadomian and Variscan orogenies
}

\author{
S.B.A. Henriques ${ }^{\text {a,* }}$, A.M.R. Neiva ${ }^{\text {b }}$, L. Tajčmanová ${ }^{c}$, G.R. Dunning ${ }^{d}$ \\ a GeoBioTec, LNEG: Geology, Hydrogeology and Coastal Geology Department, Estrada da Portela, Bairro do Zambujal, Ap.7586-Alfragide, 2610-999 Amadora, Portugal \\ b GeoBioTec, Department of Earth Sciences, University of Coimbra, 3030-790 Coimbra, Portugal \\ c Department of Earth Sciences, ETHZ, Clausiusstrasse 25, CH-8092 Zurich, Switzerland \\ d Earth Sciences Department, Memorial University, St. John's, NL A1B 3X5, Canada
}

\section{A R T I C L E I N F O}

\section{Article history:}

Received 7 May 2017

Accepted 21 November 2017

Available online 23 November 2017

\section{Keywords:}

Cadomian arc

Trondhjemite

Garnet amphibolite

Variscan metamorphism

Geochemistry

\begin{abstract}
A B S T R A C T
The Mouriscas Complex is a deformed and metamorphosed predominantly mafic igneous complex of Ediacaran and Ordovician age and crops out at the Ossa-Morena/Central Iberian zone boundary in the Iberian Massif, Central Portugal. It comprises amphibolite with Neoproterozoic protoliths (ca. $544 \mathrm{Ma}$ ), protomylonitic felsic dykes derived from younger trondhjemitic protoliths (ca. $483 \mathrm{Ma}$ ) and garnet amphibolite derived of even younger dioritic protoliths (ca. $477 \mathrm{Ma}$ ). The protoliths of the Neoproterozoic amphibolites are calc-alkaline magmas of basic to intermediate compositions with intraplate and active continental margin affinities and are considered to represent the final phase of the Cadomian arc magmatism. They are interpreted to have originated as coarse-grained intrusions, likely gabbro or diorite and generated from the partial melting of meta-igneous lower crust and mantle. Their emplacement occurred near the Cadomian metamorphic event dated at ca. $540 \mathrm{Ma}\left(P=7-8 \mathrm{kbar}\right.$ and $\left.T=640-660^{\circ} \mathrm{C}\right)$ which is interpreted to represent a continental collision. During the Late Cambrian-Early Ordovician an extensional episode occurred in the central-southern Iberian Massif and was also observed in other areas of the Variscan Orogen. It led to mantle upwelling and to the development of an aborted intracratonic rift located at the Ossa-Morena/Central Iberian zone boundary and to the opening of the Rheic Ocean to the south of the area studied in present coordinates (i.e., between the Ossa-Morena and South Portuguese Zones). This event has been dated at ca. $477 \mathrm{Ma}$ and was responsible for the melting of deep ancient mafic crust and mantle with formation of bimodal magmatism in an intra-plate setting, as indicated by the protoliths of the protomylonitic felsic dykes with trondhjemitic composition and of the garnet amphibolite. Subsequent Variscan metamorphism took place under amphibolite facies conditions $\left(P=4-5.5 \mathrm{kbar} ; T=600-625^{\circ} \mathrm{C}\right)$ at lower $P$ - $T$ conditions than the Cadomian metamorphic event. It was followed by greenschist retrogression as suggested by the appearance of actinolite rims and formation of chlorite and epidote.
\end{abstract}

(c) 2017 Elsevier B.V. All rights reserved.

\section{Introduction}

The Cadomian Orogen formed in an active margin setting at the periphery of Gondwana, in the period ca. 750-540 Ma (e.g. Linnemann et al., 2007 and references therein), which was followed by the Early Palaeozoic rifting from $\mathrm{ca}$. 530 to $485 \mathrm{Ma}$ and opening of the Rheic Ocean (e.g. Nance et al., 2010; Sánchez-García et al., 2008 and references therein). The later northward movement of Gondwana and its marginal terranes resulted in closure of the Rheic Ocean during the DevonianCarboniferous leading to the Variscan orogeny (e.g. Strachan et al.,

\footnotetext{
* Corresponding author.

E-mail addresses: susana.henriques@lneg.pt (S.B.A. Henriques), neiva@dct.uc.pt (A.M.R. Neiva), lucie.tajcmanova@erdw.ethz.ch (L. Tajčmanová), gdunning@mun.ca (G.R. Dunning).
}

2014 and references therein). The Rheic Ocean separated the great paleocontinents of Gondwana and Laurussia as the principal interior ocean of the Paleozoic, and it is the evolution of this ocean that dominates the geology of southern Europe, eastern North America and northern Africa (Nance et al., 2012 and references therein).

Fragments of the Cadomian Orogen are found in the Armorican, Bohemian and Iberian Massifs (e.g. Bandrés et al., 2004; Inglis et al., 2005; Linnemann et al., 2008; Nance et al., 2008 and references therein). In the Iberian Massif a well-preserved Cadomian basement crops out at the Olivenza-Monesterio Antiform (e.g. Ordóñez-Casado, 1998 and references therein) and at the Ossa-Morena/Central Iberian zone boundary, which was affected by tectonometamorphic events of the Cadomian and Variscan orogenies (e.g. Dallmeyer and Quesada, 1992; Eguíluz et al., 2000; Henriques et al., 2015; Ordóñez-Casado, 1998; Ribeiro et al., 2009). This boundary, where the Mouriscas Complex 